\title{
THE CONCEPTUAL BASIS FOR THE DEVELOPMENT OF SMALL BUSINESS POTENTIAL IN THE REGION
}

\author{
Nataliia Hryshyna ${ }^{1}$ \\ Admiral Makarov National University of Shipbuilding, Ukraine
}

Iryna Khmarska²

Pervomaisk Polytechnic Institute, Admiral Makarov National University of Shipbuilding, Ukraine

\begin{abstract}
The article deals with the study of conceptual foundations of the development of the potential of small business in the region. The purpose of the article is to study the essence and features of small business potential and to form conceptual foundations of its development at the regional level. The subject of the research is theoretical, methodological, and practical aspects of the potential of small business in providing a sustainable economic growth. In the course of the research, the following general scientific and special methods are used: dialectical, system analysis, graphical analysis, matrix, mathematical modelling in economics, and logical generalization of results. The essence of the category "small business potential of the region" is studied; it should be understood as a complex system of balanced and mutually related elements in the form of conditions, resources, and opportunities for small business enterprises in the region to conduct production, economic, commercial, and other activities in order to ensure public needs in terms of sustainable economic growth. Methodological principles for forming a conceptual model for the development of small business potential and the scheme of generalized stages of its implementation (preparatory, analytical, operational stages and stage of introduction and implementation) are determined, the implementation of which will help to determine the preconditions for the formation of strategic potential, assess its modern quantitative and qualitative composition, and make a forecast of prospects of the use in ensuring sustainable economic growth. It is proposed to use economic and mathematical models, by means of which it is possible to quantitatively describe the connection between the input indicators of the economic system and the performance indicator. In order to substantiate directions of development of the potential of small business in the region in view of its role in creating new jobs and increasing employment as one of the important indicators of sustainable economic growth, it is proposed to build an economic-mathematical model, the main parameters of which are generalized indicators of the level of labour potential, material-technical potential, financial potential, innovation and infrastructure potential. The use of the proposed methodological approach to the substantiation of directions for developing small business potential will determine possibility and probability of selecting necessary measures to improve certain of its structural elements and their consideration in the development of small business development programs, the selection of sources of its financing, which should facilitate the intensification of business activity as an important factor of flexibility of the regional economy, ensuring competitive activities, capable of becoming a foundation for the renovation of economic growth.
\end{abstract}

Key words: potential, small business, region, strategic growth priorities.

JEL Classification: M2, R11, L21

\section{Introduction}

Among the main strategic priorities of ensuring socioeconomic development of Ukraine, a shift in emphasis to the fulfilment of inner potential of regions, introduction of effective mechanisms and tools for local and regional development incentives, intensification of business activities are identified. Thus, the determination of directions to develop and increase the efficiency of the use of small business potential as an important element of the economic system is one of the prerequisites for the provision of sustainable economic growth. Formation of strategic directions of development of small business potential requires developing corresponding conceptual

Corresponding author:

${ }^{1}$ Department of Management, Admiral Makarov National University of Shipbuilding.

E-mail: natalia.gryshyna@nuos.edu.ua

${ }^{2}$ Department of Economics and Industrial Management, Pervomaisk Polytechnic Institute, Admiral Makarov National University

of Shipbuilding.

E-mail: hmarskij@inbox.ru 
foundations. The purpose of the article is to study the essence and features of small business potential and to form conceptual foundations of its development at the regional level. The subject of the research is theoretical, methodological, and practical aspects of the potential of small business in providing a sustainable economic growth. Research methods are: dialectical - to find regularities, principles, and factors of promoting the development of small business potential; system analysis - to reveal the essence of elements of small business potential; graphical analysis - for a schematic presentation of theoretical and practical provisions of the study; matrix, mathematical modelling in economics, logical generalization of results - to develop recommendations on the formation of conceptual foundations for the development of small business potential of the region.

\section{Analysis of recent research and publications}

World economic science pays considerable attention to studying small business as one of the regular factors of socio-economic advance of countries. A fundamental contribution in the theory of entrepreneurship is made by M. Weber, P. Drucker, W. Sombart, R. Cantillon, B. Karloff, A. Marshall, F. Knight, J.B. Say, B. Szanto, A. Smith, J. Thünen. Among domestic scholars and researchers of aspects of small business development, Yu. Bazhal, H. Bilous, Z. Varnalii, A. Halchynskyi, V. Herasymchuk, A. Danylenko, Ya. Zhalilo, S. Zlupko, I. Komarnytskyi, M. Krupka, V. Kuznietsov, I. Lemeshevskyi, V. Onyshchenko, V. Pyla, S. Reverchuk, M. Syzonenko, D. Stechenko, O. Tymchenko, S. Chernenko, and others should be mentioned. To the study of the potential of the small business, in particular, at the regional level, determination of methodological foundations for its evaluation and mechanisms for improving the efficiency of the use, scientific works of domestic scholars such as A.I. Butenko, H.V. Karpinska, Ye.V. Lazarieva, V.I. Liashenko, I.M. Saraieva, N.L. Shlafman and others (2014) are devoted. They note that business potential of the region is a complex phenomenon that reflects "a set of framework conditions of entrepreneurial activity, availability of resources and possibilities to carry out this activity, a region's disposition toward this activity, and the population's business activity implemented in certain period" (A.I. Butenko, N.L. Shlafman, Ye.V.Lazarieva, 2012). The same thought is also observed in studies of O.V. Likhanos (2010), who consider that business potential is determined by its socio-economic structure and conditions created for its formation and implementation. However, in justice to results achieved, one can distinguish a number of insufficiently elaborated issues of formation and development of small business potential (SBP) as a strategic factor of socio-economic changes in the economic growth.

\section{The essence and structure of small business potential of the region}

Ukrainian choice of the European way of development and an intention to become an associated member of the EU forms new vectors of development and implementation of regional policy. Determination of a new role of state regional policy as the main instrument for providing complex development of territories, activation of small and medium business, and job creation in regions serve the main ways of Ukraine's formation as a modern democratic state (Derzhavna stratehiia rehionalnoho rozvytku na period do 2020 roku, 2014). These priorities are also mentioned in updated State Strategy of Regional Development for the period until 2020 (2014), which fulfilment will contribute to the acceleration of reformation of certain spheres of regional development, resource mobilization and optimization of their use, increase in the economic initiative and business activity.

It should be noted that regional development programs for small and medium business also emphasize on the achievement of these objectives. However, evaluation of the state and problems of functioning of the small business, analysis of the implementation of appropriate Development Programs of previous periods indicate a low level of their fulfilment, the main cause of which was an insufficient level of financing, law quality of their implementation, weak infrastructure support, etc. (Ofitsiinyi sait Derzhavnoho komitetu z pytan rehuliatornoi polityky ta pidpryiemnytstva (20062013); Ofitsiinyi sait Ukrainskoho fondu pidtrymky pidpryiemnytstva).

It is worth noting that small business potential as an economic category can be considered from different points of view, highlighting herewith features, regularities, principles, and factors of its formation and use. The main features and regularities of business potential formation include:

- interrelation and balance of elements of potential that has to function simultaneously and together;

- alternative nature of potential elements that may in one or another way replace each other;

- the dynamism of the formation of the potential, which makes it impossible to determine it by mechanical addition of the constituent elements;

- entrepreneurial potential can be independently transformed with the emergence of new constituent elements;

- flexibility, adaptability, and sustainability of the potential, which will promote the preservation of its integrity when implementing external influences; etc.

In our opinion, the concept of "potential of small business" should be considered in the broad sense as an integrated category, which includes entrepreneurial potentials of different levels (entrepreneurial potential of a person, enterprise, region, country). At the same 
time, business potential of each next level includes in its composition as the corresponding potentials of lower levels, so the necessary conditions for their formation and implementation. In addition, each of the components of the multi-level structure of the SBP is in a relationship and interaction with the elements of both higher and lower levels. Consequently, business potential of a higher level is not the result of a simple summing of potentials of lower levels but has emergent properties, when the effect of these potentials increases, which causes its increase and development. After studying different points of view of domestic and foreign scholars in determining the category of "business potential" and taking into account the basic properties and regularities of its formation, we propose to understand "the potential of small business in the region" as a comprehensive system of balanced and mutually related elements in the form of conditions, resources, and opportunities for carrying out production and economic, commercial, and other activities by small business enterprises in order to provide public needs in conditions of sustainable economic growth.

\section{Formation of conceptual foundations for the development of SBP of the region}

Therefore, taking into account all of the above, one should emphasize the need to formulate conceptual foundations for the development of SBP as one of the effective ways for ensuring the economic and social development of both individual regions and the country as a whole. This requires the development of an appropriate Concept, which should contain methodological and constructive provisions, identify its main components (the main purpose, priority directions, goals), as well as implementation mechanisms. Thus, among the main methodological principles for the formation of such a model, the following should be noted:

- the principle of recognition of the priority of entrepreneurial activity and its subordination to solving problems of sustainable development, implementation of an innovative model of economic development;

- the principle of ensuring an integrated system approach, according to which the system of support for SBP development should be an appropriate socioeconomic system of goals, tasks, means, and rules for their achievement, conditions of implementation, etc.;

- the principle of using the general theory of management, which will allow regulating the sequence of actions and performers of tasks defined for the formation and implementation of the strategy for the development of SBP in the medium and long term;

- the principle of flexibility, which involves taking into account multivariate forecasts of the development of individual components of business potential under the influence of changes in the external and internal environment;

- the principle of reconciling goals of the state and small business in the direction of intensifying innovation and investment processes, reducing costs, and using resource-saving technologies, focusing on the intensive type of development of large, medium, and small businesses;

- the principle of marketing direction of the model for segmentation of the business sector, which will facilitate the effective implementation of measures to support and regulate entrepreneurship.

In our opinion, the formation of a model for the development of small business potential involves the implementation of four generalized stages (preparatory, analytical, operational stages, and the stage of introduction and implementation), the implementation of which will help to identify the prerequisites for the formation of strategic potential, assess its current quantitative and qualitative composition, and make a prediction about prospects of using it in ensuring sustainable economic growth (Fig. 1).

It should be noted that one of the important prerequisites for the formation of a qualitative model for the development of small business potential is the choice of right methods for its development, the main of which, depending on the nature of the information used, are factual, expert, and also mathematical modelling in economics (Bondar, 2006; Egorova, 1999). According to the authors, for making scientifically grounded decisions, it is expedient to use economic and mathematical models, by means of which it is possible to quantify the connection between the input indicators of the economic system and the effective indicator. In this study, we use the method of correlation-regression analysis, the stages of which are the definition of the objects under study, the analysis of relations between individual variables, the selection of the rational type of econometric model. To construct a model for the formation of strategic directions for the development of small business potential, data are formed in the form of spatial and temporal sampling. In particular, these data are determined as a result of the survey of small business potential in Mykolaiv region using the system of indicators presented in Table 1 .

In order to substantiate directions of the development of small business potential in view of its role in creating new jobs and increasing employment as one of the important indicators of sustainable economic growth, it is proposed to build an economic and mathematical model, the main parameters of which are generalized indicators of the level of labour potential $\left(\mathrm{K}_{\mathrm{TT}}\right)$, material and technical potential $\left(\mathrm{K}_{\mathrm{MT \Pi}}\right)$, financial potential $\left(\mathrm{K}_{\phi \pi}\right)$, innovation and infrastructure potential $\left(K_{\mathrm{iin}}\right)$. To find out the effect of each of them on the number of working population $(\mathrm{y})$, the definition 


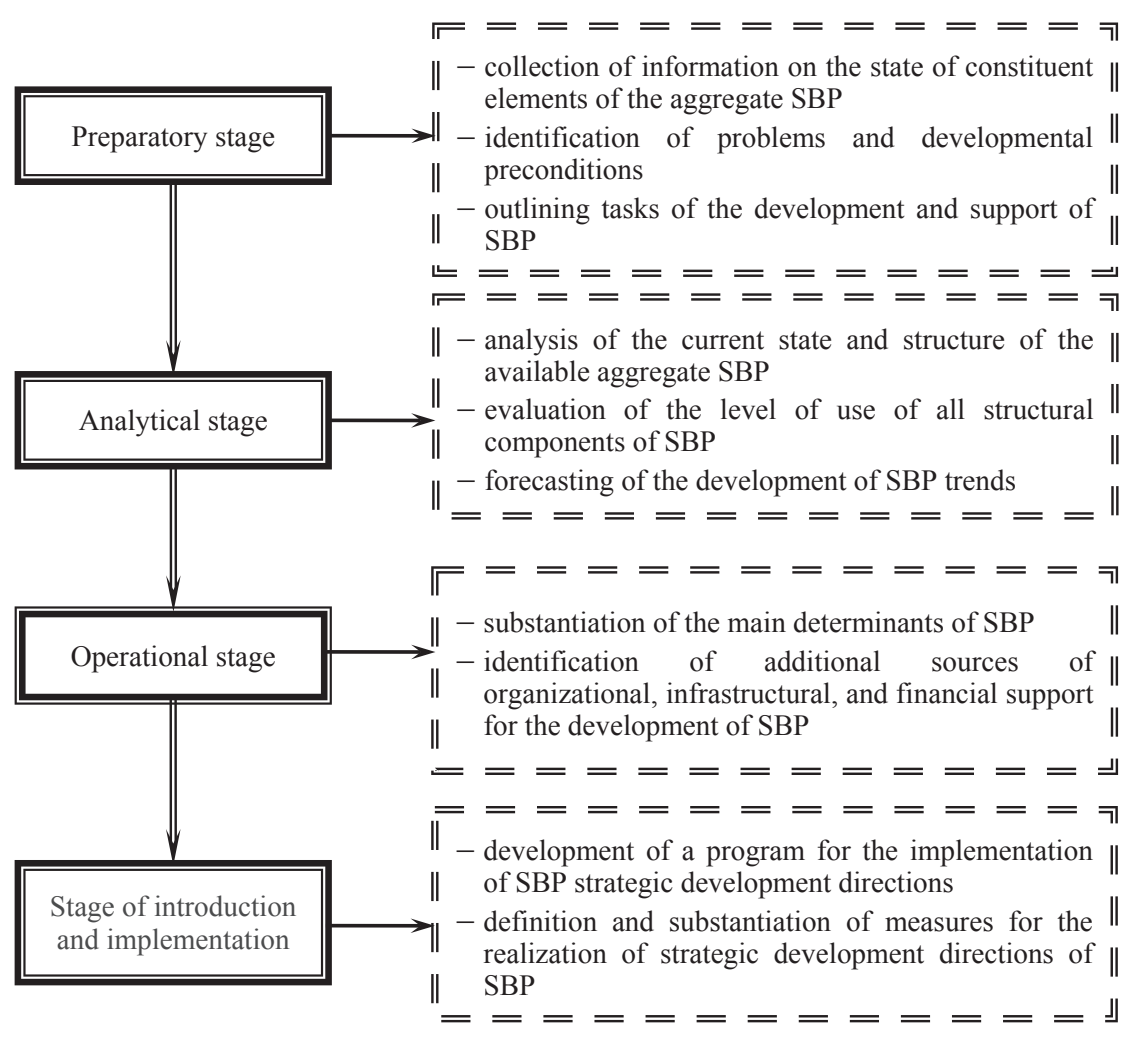

Fig. 1. Generalized chart of the process of formation and realization of strategic directions for the development of small business potential

Table 1

The system of individual and generalized indicators of the level of SBP use for the formation of strategic directions of its development

\begin{tabular}{|c|c|c|}
\hline Block & Individual indicators of the $i$-th block & Generalized indicators \\
\hline \multirow{3}{*}{$\begin{array}{c}\text { Block } 1 \\
\text { Labour potential } \\
\left(\mathrm{K}_{\mathrm{rn}}\right)\end{array}$} & 1.1. Number of SBs per 10000 population $\left(\mathrm{x}_{1}\right)$ & \multirow{3}{*}{$K_{m n}=f_{1}\left(x_{1}, x_{2}, x_{3}\right)$} \\
\hline & 1.2. Number of employees in the SB sector $\left(\mathrm{x}_{2}\right)$ & \\
\hline & 1.3. Average salary in the SB sector $\left(\mathrm{x}_{3}\right)$ & \\
\hline \multirow{3}{*}{$\begin{array}{c}\text { Block } 2 \\
\text { Material and technical potential } \\
\left(\mathrm{K}_{\mathrm{MTI}}\right)\end{array}$} & $\begin{array}{l}\text { 2.1. The share of FA (fixed assets) in the SB sector in the volume of FA of the } \\
\text { region's economy }\left(\mathrm{x}_{4}\right)\end{array}$ & \multirow{3}{*}{$K_{\text {smn }}=f_{2}\left(x_{4}, x_{5}, x_{6}\right)$} \\
\hline & $\begin{array}{l}\text { 2.2. The share of CA (current assets) in the SB sector in the volume of CA of } \\
\text { the region's economy }\left(\mathrm{x}_{5}\right)\end{array}$ & \\
\hline & 2.3. The volume of investments in FA of entities of $\mathrm{SB}\left(\mathrm{x}_{6}\right)$ & \\
\hline \multirow{4}{*}{$\begin{array}{c}\text { Block } 3 \\
\text { Financial potential } \\
\left(\mathrm{K}_{\phi \mathrm{I}}\right)\end{array}$} & $\begin{array}{l}\text { 3.1. The share of } S B \text { in the total volume of sales of products (works, services) in } \\
\text { the region }\left(\mathrm{x}_{7}\right)\end{array}$ & \multirow{4}{*}{$K_{\phi n}=f_{3}\left(x 7, x_{8}, x_{9}\right)$} \\
\hline & $\begin{array}{l}\text { 3.2. The share of profitable SBs in the total volume of profitable enterprises of } \\
\text { the region }\left(\mathrm{x}_{8}\right)\end{array}$ & \\
\hline & $\begin{array}{l}\text { 3.3. Operating expenses of entities of SB from sales of products (works, } \\
\text { services) }\left(\mathrm{x}_{9}\right)\end{array}$ & \\
\hline & $\begin{array}{l}\text { 3.4. Receipt of tax payments and other revenues to the budget from SB entities } \\
\left(\mathrm{x}_{10}\right)\end{array}$ & \\
\hline \multirow{3}{*}{$\begin{array}{c}\text { Block } 4 \\
\text { Innovation and infrastructure } \\
\text { potential }\left(\mathrm{K}_{\mathrm{in}}\right)\end{array}$} & 4.1. Infrastructure development costs per capita $\left(\mathrm{x}_{11}\right)$ & \multirow{3}{*}{$K_{i n}=f_{4}\left(x 11, x_{12}, x_{13}\right)$} \\
\hline & 4.2. The level of security of SBs by infrastructure objects $\left(\mathrm{x}_{12}\right)$ & \\
\hline & 4.3. Level of business activity $\left(\mathrm{x}_{13}\right)$ & \\
\hline
\end{tabular}

of the relationship between them, an econometric model is constructed:

$Y=f\left(K_{T \Pi} ; K_{M \Pi} ; K_{\Phi \Pi} ; K_{I I} ; u\right)$,

where $\mathrm{u}$ - stochastic component of the model.

According to the data of the observation, the use of potential of small business in certain raions of Mykolaiv region, generalized indicators of the level of labour potential $\left(\mathrm{K}_{\mathrm{TT}}\right)$, material and technical potential $\left(\mathrm{K}_{\mathrm{MTT}}\right)$, financial potential $\left(\mathrm{K}_{\phi \pi}\right)$, innovation and infrastructure potential $\left(\mathrm{K}_{\mathrm{iin}}\right)$ (Hryshyna, 2016) are determined. In determining the parameters of the econometric model, the method of least squares ( $1 \mathrm{MNK}$ ) was used (Bondar, 
2006; Ostrovskyi, Hostryk, Dobrunik, Radova, 2012). In order to select the best specification, we will analyse the constructed models (Table 2).

Table 2

Econometric characteristics of the model

\begin{tabular}{|l|c|c|}
\hline \multirow{2}{*}{\multicolumn{1}{|c|}{ Indicators }} & \multicolumn{2}{c|}{ Characteristics of the model } \\
\cline { 2 - 3 } & Linear & Exponential \\
\hline Determination coefficient & 0,904 & 0,927 \\
\hline $\begin{array}{l}\text { Adjusted coefficient of } \\
\text { determination }\end{array}$ & 0,892 & 0,917 \\
\hline The value of Fisher's criterion & 71,18 & 95,68 \\
\hline Critical values of Fisher's criterion & 2,69 & \\
\hline
\end{tabular}

Consequently, the proposed models are adequate, and the criterion for choosing the best of them is the adjusted coefficient of determination, which determined the choice of the exponential model. That is, the relationship between the number of employed population and the generalized indicators of the potential of small business in the region $\left(K_{T \Pi} ; K_{M \Pi} ; K_{\Phi \Pi} ; K_{I \Pi}\right)$ will describe the exponential function of this type:

$\hat{y}=7,97 \cdot K_{T \Pi}^{0,55} \cdot K_{M \Pi}^{-0,78} \cdot K_{\Phi \Pi}^{0,15} \cdot K_{I \Pi}^{0,45}$

It is worth noting that the calculated values of the determination coefficient $\mathrm{R}^{2}=0,927$, Fischer criterion $\mathrm{F}_{\text {розр }}=71,18\left(\mathrm{~F}_{\text {табл }}=2,69\right)$ and the adjusted coefficient of 0,917 indicate sufficient compliance with the empirical data of the proposed econometric model.

In the process of forming strategic directions of the development of SBP, it is necessary to have an information base, which is created at the stage of strategic analysis. Conducting a strategic analysis of the status of SBP should meet the requirements of purposefulness, objectivity, timeliness, systemacity. In the market conditions of management at the stage of strategic analysis, the factors of the external environment and the internal environment are systematically analysed in order to determine the current state of the PMP and to identify conditions for its further development.

\section{Conclusions}

In order to identify strategic directions of the development of small business potential, a methodical approach based on the use of a multifactorial dynamic model, the implementation of which allows determining the degree of influence of the effectiveness of using its constituent elements (labour, material, technical, financial, innovation and infrastructure potential) on the main indicators of economic growth, is developed. Since ensuring such a growth requires the fulfilment of key conditions, among which are: decent living standards, education, equality, long and healthy life, favourable economic and environmental conditions, the very creation of new jobs is a priority in identifying strategic guidelines for the development of small businesses potential. The use of the proposed methodological approach to the substantiation of directions for developing small business potential will determine possibility and probability of selecting necessary measures to improve certain of its structural elements and their consideration in the development of small business development programs, the selection of sources of its financing, which should facilitate the intensification of business activity as an important factor of flexibility of the regional economy, ensuring competitive activities, capable of becoming a foundation for the renovation of economic growth.

\section{References:}

Bondar, I. O. (2006). Modeliuvannia vzaiemodii mizh malym pidpryiemstvom ta velykym vyrobnychym obiednanniam [Modeling the interaction between a small business and a large industrial association]. Municipal economy of cities, vol. 73, pp. 280-289.

Butenko, A. I., Shlafman, N. L., Lazarieva, Ye. V. (2012). Potentsial maloho pidpryiemnytstva v paradyhmi staloho rozvytku [Potential of small business in the paradigm of sustainable development]. Odesa: Interprint. [in Ukrainian]. Butenko, A. I., Shlafman, N. L., Lazarieva, Ye. V., Saraieva, I. M., Karpynska H. V. \& V. V. Lukashchuk (2014). Zmitsnennia potentsialu maloho pidpryiemnytstva u zabezpechenni staloho rozvytku Ukrainskoho Prychornomoria [Strengthening the potential of small businesses in ensuring the sustainable development of the Ukrainian Black Sea region]. Odesa: Interprint. [in Ukrainian].

Derzhavna stratehiia rehionalnoho rozvytku na period do 2020 roku (2014) [State Strategy for Regional Development up to 2020]. Retrieved from: http://zakon2.rada.gov.ua/laws/show/385-2014-\%D0\%BF.

Egorova, N. E. (1999). Modelirovanie deyatel'nosti malogo predpriyatiya, funktsioniruyushchego v ekonomicheskom simbioze s krupnym promyshlennym ob"ektom [Modeling the activity of a small enterprise operating in economic symbiosis with a large industrial facility]. Economics and Mathematical Methods,

Hryshyna,N.V.(2016).Pidvyshchennia efektyvnostivykorystannia potentsialumaloho pidpryiemnytstvauzabezpechenni stiikoho ekonomichnoho zrostannia [Improvement of efficiency of small business potential use in supporting region's sustainable economic growth]. Extended abstract of candidate's thesis. Odesa: IPREED NANU [in Ukrainian].

Likhanos, E. V. (2010). Formirovanie predprinimatel'skogo potentsiala kakfaktor razvitiya biznes-sfery [Formation of entrepreneurial potential as a factor in the development of the business sphere]. Extended abstract of candidate's thesis. Stavropol': StGAU [in Russian].

Ofitsiinyi sait Derzhavnoho komitetu z pytan rehuliatornoi polityky ta pidpryiemnytstva (2006-2013). Uzahalneni zvity pro stan vykonannia rehionalnykh prohram rozvytku maloho pidpryiemnytstva $v$ Ukraini. [Generalized reports 
on the state of implementation of regional programs for the development of small business in Ukraine]. Retrieved from: http://www.dkrp.gov.ua.

Ofitsiinyi sait Ukrainskoho fondu pidtrymky pidpryiemnytstva [Official site of the Ukrainian Business Support Foundation]. Retrieved from: http://ufpp.gov.ua.

Ostrovskyi, P. I, Hostryk, O. M., Dobrunik, T. P., Radova, O. V. (2012). Modeliuvannia ekonomichnykh protsesiv [Models of economical processes]. Odesa, ONEU. [in Ukrainian].

Rehionalnyi vymir sotsialno-ekonomichnoho rozvytku i zasady novoi rehionalnoi polityky (2013). [Regional dimension of socio-economic development and the foundations of a new regional policy], Kyiv: NISD. Vol. 2, pp. 17-29. 